Jurnal Ekonomi dan Industri

e-ISSN: 2656-3169

Volume 21, No. 1, Januari-April 2020

p-ISSN: 0853-5248

\title{
PENGARUH KETERAMPILAN WIRAUSAHA DAN PENGALAMAN USAHA TERHADAP KEBERHASILAN KEWIRAUSAHAAN
}

\author{
Keke Arnesia Iskandar ${ }^{1)}$ \\ 1) Mahasiswa Program Studi FE UNKRIS \\ Arief Syah Safrianto ${ }^{2}$ ) \\ 2) Dosen Program Studi Manajemen FE UNKRIS \\ Alamat: Kampus UNKRIS, Jatiwaringin Jakarta Timur \\ Email: Ariefsafrianto@gmail.com
}

\begin{abstract}
The purpose of this study was to determine the effect of entrepreneurial skills and business experience on entrepreneurial success (Case study of the food and beverage sector in Bojong Rawalumbu village). The number of population used was 158 taken from the food and beverage sector entrepreneurs in the Bojong Rawalumbu village and the number of samples used in this study was 97 respondents. This research is a quantitative study, using multiple linear regression analysis. The results of this study were obtained simultaneously showing a positive and significant effect of entrepreneurial skills on entrepreneurial success and simultaneously business experience had a positive and significant effect on entrepreneurial success. Partially, there is a positive and significant influence of entrepreneurial skills and business experience on entrepreneurial success. And there are suggestions given, namely in the Bojong Rawalumbu village so that entrepreneurs in the food and beverage sector are more concerned with holding routine skills development training programs in order to gain more business experience, to achieve entrepreneurial success.
\end{abstract}

Keywords: Entrepreneurial skills, business experience, entrepreneurial success

\section{PENDAHULUAN}

Perkembangan usaha kecil menengah atau kegiatan berwirausaha di Indonesia terus berkembang pesat. Bermula dari tahun 1998 dimana perekonomian Indonesia dalam sektor perusahaan besar menurun dan melemahkan kondisi perekonomian di Indonesia. Para pemilik perusahaan besar yang terpaksa menutup usahanya karena tidak mampu dalam bidang finansial jelas saja memanfaatkan kekuatan finansial yang rendah dengan memulai beralih untuk berwirausaha demi mencukupi kebutuhan hidup. Menurut pendapat Kepala Departemen Pengembangan kewirausahaan Bank Indonesia (Yunita, 2018) saat ini kondisi kewirausahan di Indonesia mendominasi unit usaha hingga 99,9\% dari total 57,89 juta. Angka tersebut juga berkontribusi terhadap penyerapan tenaga kerja, produk domestik bruto (PDB) hingga ekspor.Pada saat ini kewirausahaan juga menjadi penggerak ekonomi yang diperhatikan oleh pemerintah.Hal ini menjadi perhatian menarik dalam permasalahan khusus dalam penelitian ini.

Kondisi kewirausahaan di Bekasi saat ini menduduki status baik. Menurut visi dan misi Walikota Bekasi periode 2018-2023 Bpk. Rahmat Effendi bertujuan untuk membangun kota Bekasi dengan membina 100 pengusaha baru dalam tingkat UMKM khusus di bidang minuman dan makanan. Dengan dukungan yang baik dari pihak pemerintahan daerah Bekasi, kini pengusaha baru mempunyai kesempatan untuk mendapatkan keuntungan dengan keterampilan berwirausaha serta pengalaman usaha yang akan di bina oleh Kelompok atau Organisasi yang disiapkan Walikota Bekasi guna 
membantu mengasah keterampilan berwirausaha serta pengalaman usaha para pelaku usaha dan warga Bekasi yang ingin menjadi pelaku usaha. Menurut penelitian terdahulu yang dilakukan oleh (Megantoro, 2015) kewirausahaan merupakan kelompok usaha yang paling dapat bertahan ketika krisis ekonomi melanda negri ini. Dari pengertian kewirausahaan tersebut yang dikemukakan oleh beberapa ahli, tentu saja berlandaskan beberapa faktor yang mempengaruhi terjadinya keberhasilan kewirausahaan.

Faktor yang mempengaruhi keberhasilan kewirausahaan menurut Alma (2011) adalah Percaya Diri, Inisiatif, Memiliki Motif Berprestasi, Memiliki Jiwa Pemimpin, Berani, Orisinalitas. Sedangkan menurut Suryana (2011) keberhasilan usaha dapat diukur melalui tingkat pendapatan, bertambahnya produktivitas usaha, dan punya citra yang baik dimata pelanggan. Adapun pendapat menurut peneliti terdahulu Keterampilan atau personal entrepreneur skill merupakan pengaruh yang besar dalam berwirausaha terhadap pertumbuhan usaha kecil yang berkelanjutan (Muhyi, 2012). Sedangkan menurut Kenneth (2013) keterampilan wirausaha akan berhasil dengan memiliki keterampilan dalam perencanaan dan penganggaran dalam menyusun strategi bisnis bidang pemasaran untuk menyediakan produk yang menarik dan inovatif, bertindak cepat mendeteksi perubahan lingkungan, menilai masalah penualan sebagai cara mempertahankan hubungan dengan pelanggan, fokus pada kualitas produk sehingga dapat meraih pangsa pasar dan menarik serta mempertahankan karyawan yang kompeten. Selanjutnya adalah salah satu faktor lain yang menyebabkan terjadinya kewirausahaan.

Faktor terjadinya kewirausahaan kali ini adalah pengalaman usaha. Penelitian terdahulu tentang pengalaman berpengaruh terhadap kewirausahaan menyatakan bahwa, pengalaman adalah salah satu faktor yang mempengaruhi terhadap kewirausahaan (Sustanto, 2010). Sedangkan pengalaman usaha bisa diartikan sebagai indikator terbaik bagi keberhasilan usaha kecil dan menengah Pradanawati (2015). Hal ini bisa di buktikan dari pengasuhan orang tua yang berwirausaha, tanpa sengaja anak-anak mereka terdidik mandiri dan hal tersebut mendorong niat personal sang anak untuk berwirausaha. Meski tidak ada studi banding dengan wirausaha yang orang tuanya bukan wirausahawan, relasi dengan orang tua yang berwirausaha menjadi aspek penting sang anak untuk memiliki keinginan berwirausaha. Dapat disimpulkan pula pengalaman usaha dalam mengelola usaha kecil berpengaruh terhadap keberhasilan kewirausahaan skala kecil dan menengah. Karena, pengalaman ini bisa diperoleh dari pola asuhan orang tua yang berprofesi wirausaha, pengalaman mengelola usaha skala kecil sebelumnya, atau terlibat dalam kegiatan-kegiatan berwirausaha baik secara tidak langsung atau secara langsung.

Beberapa faktor yang sudah di jelaskan pada latar belakang tersebut maka, peneliti tertarik untuk mengangkat masalah kewirausahaan yang dikaitkan oleh beberapa faktor yang mempengaruhi keberhasilan kewirausahaan yang akan di uji akurasinya di Kelurahan Bojong Rawalumbu studi kasus sektor makanan dan minuman.

Tujuan penelitian ini untuk menganalisis pengaruh keterampilan wirausaha dan pengalaman usaha terhadap keberhasilan kewirausahaan (Studi kasus pengusaha sektor makanan dan minuman di Kelurahan Bojong Rawalumbu).

\section{LANDASAN TEORI}

\section{Keberhasilan Kewirausahaan}

Kewirausahaan adalah proses dinamik untuk menciptakan tambahan kemakmuran. Tambahan kemakmuran ini diciptakan oleh individu wirausaha yang menanggung resiko, menghabiskan waktu, dan menyediakan berbagai produk dan jasa (Alma, 2011). Melalui kewirausahaan dapat tercipta suatu lapangan pekerjaan sehingga tidak hanya pemilik usaha 
(wirausaha) saja yang sejahtera melainkan juga masyarakat di sekitarnya. Dan menurut penelitian terdahulu yang dilakukan Megantoro (2015) kewirausahaan merupakan kelompok usaha yang paling dapat bertahan ketika krisis ekonomi melanda negri ini. Pengertian menurut para ahli lain disampaikan oleh Bastian (2011) yang mengemukakan bahwa kewirausahaan bisa dihasilkan dari learning by doing, juga dari semangat mengambil risiko tanpa takut, bukan lewat pendidikan khusus kewirausahaan atau manajemen. Sedangkan keberhasilan kewirausahaan menurut pendapat Irawan dan Mulyadi (2016) adalah seorang wirausaha yang berhasil membuat usaha yang dirintisnya berhasil ialah seseorang yang meningkatkan sumber daya yang tersedia, visi dan misi yang mampu diwujudkan, tingkat pendapatan yang meningkat, produktivitas usaha yang berkembang, citra yang baik dari pelanggan dan mampu bersaing dengan pelaku usaha lainnya.

Jadi, dapat di simpulkan bahwa keberhasilan kewirausahaan bisa dimiliki oleh pelaku usaha jika memiliki semua faktor personal yang sudah dijabarkan sebelumnya dan dilihat dari tingkat pendapatan usaha itu sendiri. Keberhasilan usaha juga bisa dimiliki apabila pelaku usaha dapat merencanakan dan menganggarkan dana yang dimiliki untuk memaksimalkan strategi pemasaran, bertindak secara cepat dan tepat untuk mendeteksi perubahan lingkungan, menciptakan produk yang berkualitas, menari, serta inovatif guna mempertahankan hubungan baik terhadap pelanggan, dan menguasai pangsa pasar. Keberhasilan kewirausahaan juga mempunyai faktor penting bagi pelaku usaha. Pelaku usaha harus mempunyai keterampilan usaha dan pengalaman usaha. Oleh karena itu, kedua faktor yang dapat mempengaruhi keberhasilan kewirausahaan tersebut akan di teliti dalam penelitian ini.

Kewirausahaan memiliki berbagai faktor yang sangat diperlukan oleh para pelaku wirausaha dan dapat ditanamkan melalui pendidikan kewirausahaan. Menurut Alma (2011) serta Irawan dan Mulyadi (2016) nilai-nilai kewirausahaan tersebut antara lain: Percaya Diri, Inisiatif, Memiliki Motif Berprestasi, Memiliki Jiwa Pemimpin, Berani, Orisinalitas, Tingkat Pendapatan, Tingkat Produktivitas, Visi dan Misi yang tercapai dan Citra Baik dari Pelanggan.

\section{Keterampilan Wirausaha}

Gibb dalam Fitriati dan Hermiati (2010) menyatakan bahwa proses kewirausahaan meliputi perilaku, keterampilan dan atribut yang dimiliki seseorang dalam kewirausahaan. Dalam mengembangkan perilaku kewirausahaan, diperlukan proses yang mencakup identifikasi sifat-sifat yang berhubungan dengan kewirausahaan. Baik dalam bentuk keterampilan dan atribut yang melekat dalam kewirausahaan. Pengertian berbeda juga dinyatakan oleh Muhyi (2012), menurutnya keterampilan adalah salah satu ciri khas berwirausaha dan menjadi salah satu faktor pendukung keberhasilan berwirausaha pada usaha kecil dan mengengah. Suryana (2011) keterampilan wirausaha adalah keberhasilan seseorang wirausaha dalam mengimplementasikan kompetensi yang di milikinya dengan baik secara ilmu pengetahuan yang di implementasikan secara tepat dan kualitas invidu melaksanakan kegiatan berwirausaha. Menurut Kenneth (2013) keberhasilan usaha dapat tercipta apabila pelaku usaha mempunyai keterampilan individual lebih. Seperti, keterampilan manajerial dan keterampilan dalam mempertahankan kualitas produk yang di produksi.

Dalam pengertian yang sudah di jelaskan oleh para ahli, dapat disimpulkan bahwa keterampilan wirausaha bisa dimiliki oleh seseorang yang berniat menjadi pelaku usaha. Tidak hanya sekedar niatan belaka, pelaku usaha juga dituntut untuk mempunyai ide kreatif dan berinovasi terhadap keterampilan individu yang di miliki. Keterampilan 
wirausaha dapat menjadi faktor pendorong pelaku usaha untuk mempertahankan kualitas produk yang dimiliki, citra baik yang didapatkan dari pelanggan, dan tingkat pendapatan pasti meningkat jika pelaku usaha terampil menuangkat segala keterampilan yang dimiliki serta ilmu pengetahuan yang bisa memicu berkembangnya keterampilan wirausaha. Secara tidak sadar pelaku usaha dapat menjadi berkembang keterampilannya karena berkecimpung langsung dalam kegiatan-kegiatan berwirausaha. Hal ini menjadikan kebiasaan yang baik dan menjadikan pelaku usaha peka terhadap perubahan di lingkungan usaha baik lingkungan internal maupun lingkungan eksternal.

Keterampilan memiliki beragam indikator untuk kepentingan pelaku wirausaha agar bisa tetap menjaga konsistensi keterampilan hingga kreatifitas juga lebih berkembang baik. Berikut ini adalah indikator keterampilan menurut Chang dan Rieple (2013) dan Kenneth (2013) yaitu, technical skill, management skills, entrepreneurship skills, personal maturity skills, Fokus dalam Kualitas Produk, dan Peka terhadap Lingkungan Internal atau Eksternal.

\section{Pengalaman Berwirausaha}

Menurut Sustanto (2010) Pengalaman adalah salah satu faktor yang mempengaruhi terhadap kewirausahaan. Menurut Sudaresti (2014) Pengalaman sdm adalah tingkat penguasaan pengetahuan serta keterampilan seseorang dalam berwirausaha yang dapat diukur dari masa lamanya berwirausaha dan dari tingkat pengetahuan serta keterampilan yang dimilikinya. Pengalaman seseorang sangat ditentukan oleh rentan waktu lamanya seseorang menjalani pekerjaan tertentu. Pengalaman juga dapat diartikan untuk memicu potensi seseorang dalam melakukan pekerjaan tertentu termasuk pelaku usaha itu sendiri serta pengalaman juga dapat meningkatkan tingkah laku organisme seorang pelaku usaha yang dapat menghasilkan cara kerja yang lebih efektif dan efisien Megantoro (2015). Firmansyah (2013) mengemukakan bahwa pengalaman adalah pengaruh positif terhadap terbentuknya wirausaha yang berhasil. Karena, menurutnya dari pengalaman kewirausahaan telah mendorong sikap seseorang hingga mempunyai niat usaha yang tinggi.

Berikut adalah indikator dari pengalaman usaha menurut Megantoro (2015), latar belakang pribadi, bakat dan minat, sikap dan kebutuhan (attitudes and needs), kemampuan-kemampuan analitis dan manipulatif dan keterampilan dan kemampuan tehnik.

\section{METODE PENELITIAN}

\section{Metode Pengumpulan Data}

Metode pengumpulan data dalam penelitian ini menggunakan 2 (dua metode, yaitu Studi kepustakaan dan studi lapangan. Populasi sebanyak 149 UMKM, dengan menggunakan sampel jenuh, sampel sebanyak populasi yaitu 149 UMKM. Pengambilan sampel ditentukan di daerah tersebut karena tercatat pada Kecamatan Rawalumbu di Kelurahan Bojong Rawalumbu tercatat ada sebanyak 149 UMKM sektor makanan dan minuman yang terdaftar di Kelurahan Bojong Rawalumbu.

\section{Metode Analisis Data}

Metode analisis data yang digunakan dalam penelitian ini adalah analisis regresi linear berganda. 


\title{
HASIL PENELITIAN DAN PEMBAHASAN
}

\author{
Analisis Regresi Berganda
}

Tabel 1: Pengaruh Keterampilan Wirausaha dan Pengalaman Usaha Terhadap Keberhasilan Kewirausahaan

\begin{tabular}{lccccc}
\hline \multirow{2}{*}{ Variabel } & R Square & Konstanta & $\begin{array}{c}\text { Koefisien } \\
\text { Regresi }\end{array}$ & Sig. & $\boldsymbol{\alpha}$ \\
\hline $\begin{array}{l}\text { Ketram-Wira } \\
\text { Peng_Usaha }\end{array}$ & 0.862 & 9.287 & $\begin{array}{c}1.114 \\
0.544\end{array}$ & 0.000 & 0.05 \\
\hline Pengujian Signifikansi & \multicolumn{3}{c}{ Parameter } \\
\hline F hitung $>$ F tabel = 293.759 $>3.090$
\end{tabular}

Keterangan : Variabel Keberhasilan Kewirausaan

Sumber: data diolah 2020

Berdasarkan Tabel 1, secara bersama-sama keterampilan wirausaha dan pengalaman usaha terhadap keberhasilan kewirausahaan Usaha Mikro Kecil Menengah Sektor Makanan dan Minuman di Kelurahan Bojong Rawalumbu berpengaruh signifikan atau tidak, dilakukan pengujian $\mathrm{F}$ hitung dibandingkan $\mathrm{F}$ tabel atau dengan tingkat signifikansi $\mathrm{F}=0.000$ untuk $\alpha=0.05$. Berdasarkan perhitungan tersebut di atas dapat dinyatakan bahwa Nilai $\mathrm{F}$ hitung = 293,759 lebih besar dibandingkan dengan $\mathrm{F}$ tabel 3,145, artinya secara bersama-sama keterampilan wirausaha dan pengalaman usaha berpengaruh signifikan terhadap keberhasilan kewirausahaan Usaha Mikro Kecil Menengah Sektor Makanan dan Minuman di Kelurahan Bojong Rawalumbu.

Nilai $\mathrm{R}$ square sebesar 0,862 atau $86,2 \%$, hal ini berarti bahwa keterampilan wirausaha dan pengalaman usaha memberikan kontribusi kepada keberhasilan kewirausahaan Usaha Mikro Kecil Menengah Sektor Makanan dan Minuman di Kelurahan Bojong Rawalumbu sebesar 86,2\%, sedangkan sisanya sebesar 13,8\% disumbangkan oleh variabel lainnya yang tidak diteliti. Berdasarkan hasil perhitungan koefisien regresi secara simultan diperoleh persamaan regresi yaitu sebesar $\mathrm{Y}=9,287+1,114 \mathrm{X}_{1}+0,544 \mathrm{X}_{2}$

Koefisien ketrampilan wirausaha adalah sebesar 1,114, hal ini berarti bahwa jika ketrampilan wirausaha meningkat satu kali, maka keberhasilan kewirausahaan Usaha Mikro Kecil Menengah Sektor Makanan dan Minuman di Kelurahan Bojong Rawalumbu akan meningkat sebesar 1,114 kali, dengan asumsi pengalaman usaha tetap. Koefisien pengalaman usaha adalah sebesar 0,544, hal ini berarti bahwa jika pengalaman usaha meningkat satu kali, maka keberhasilan kewirausahaan Usaha Mikro Kecil Menengah Sektor Makanan dan Minuman di Kelurahan Bojong Rawalumbu akan meningkat sebesar 0,544 kali, dengan asumsi ketrampilan wirausaha tetap.

\section{Pembahasan}

Secara simultan terdapat pengaruh keterampilan wirausaha dan pengalaman usaha terhadap keberhasilan kewirausahaan. Hasil pada variabel keterampilan wirausaha dengan rata-rata responden merespon positif terhadap keberhasilan kewirausahaan, begitu juga pada variabel pengalaman usaha dengan rata-rata responden merespon positif terhadap keberhasilan kewirausahaan. Hasil penelitian ini mempunyai hasil yang sama dengan penelitian terdahulu yang dilakukan oleh Dwi Megantoro (2015), Hasil penelitian secara 
simultan keterampilan wirausaha dan pengalaman usaha memiliki pengaruh yang signifikan terhadap keberhasilan kewirasuahaan.

\section{KESIMPULAN DAN SARAN}

\section{Kesimpulan}

Berdasarkan hasil penelitian dan pembahasan pada bagian sebelum, jadi intisari dari hasil penelitian dan pembahasan tersebut dituangkan dalam bentuk kesimpulan yakni berikut ini: secara simultan keterampilan wirausaha dan pengalaman usaha terhadap keberhasilan kewirausahaan mempunyai peran positif dan signifikan.

\section{Saran}

Berdasarkan hasil penelitian dan kesimpulan penelitian yang telah diuraikan sebelumnya, disampaikan beberapa saran sebagai berikut: 1). Pembinaan keterampilan secara terus menerus terhadap para pengusaha makanan dan minuman perlu dilakukan oleh kelurahan bojong rawalumbu, sehingga peran keterampilan wirausaha dapat dirasakan oleh para pengusaha makanan dan minuman serta berdampak pada keberhasilan kewirausahaannya. 2). Kelurahan bojong rawalumbu perlu memperhatikan standar pengalaman usaha yang guna bertujuan untuk melakukan evaluasi terhadap keberhasilan kewirausahaan khusus sektor produk makanan dan minuman. Hal ini diharapkan bisa lebih efektif dan efisien membantu peningkatan pendapatan para pengusaha makanan dan minuman yang ada di kelurahan bojong rawalumbu. 3). Para staff kelurahan perlu mendengarkan apresiasi dari para pengusaha produk makanan dan minuman guna menyelarasi pelatihan yang akan diadakan serta menyesuaikan kebutuhan pembinaan yang para pengusaha di kelurahan bojong rawalumbu butuhkan. 4). Untuk penelitian selanjutnya, perlu menambahkan variabel lain seperti kemampuan SDM dan Inovasi yang tidak diteliti dalam penelitian ini. Serta dapat melakukan objek penilitian di sektor UMKM lain supaya hasil penelitian berikutnya menjadi lebih baik.

\section{DAFTAR PUSTAKA}

Ability-heterogeneity,entrepreneurship,andeconomicgrowth.(2010). Journal of Economic Dynamics \& Control, 522-541.

Aprilianty, E. (2012). Pengaruh Kepribadian Wirausaha, Pengetahuan, dan Lingkungan Terhadap Minat Berwirausaha Siswa SMK. Jurnal Pendidikan Vokasi, Vol.2 No.3.

Ardiana. (2010). Kompetensi SDM UKM dan pengaruhnya terhadap Kinerja UKM di Surabaya. Jurnal Manajemen dan Kewirausahaan, Vol.2.

Dbrowska, E. (2018). Experience, Aptitude, and Indiviual Differences IN Native Language Ultimate. Cognition, University of Bringham.

Dewi, G. K. (2012). Pengaruh Keterampilan, Pengetahuan, Kemampuan SDM Terhadap Kinerja UKM. Jurnal Manajemen SDM, Yogyakarta:PGRI.

Dunnette, P. F. (2011, mei 26). Kompasiana.com. Retrieved agustus 23, 2018, from http://jurnalekonomi.kompasiana.com/manajemen/2011/05/26/penelitian-danpengembangan-sumber-daya-manusia.html-

Firmasnyah, B. (2013, Universitas 11 Maret, Surakarta). Keterkaitan Pengalaman Kewirausahaan, Sikap, Norma Subyektif, Kontrol Perilaku Terhadap niat Untuk Menjadi Wirausahawan (Studi pada para perajin Batik di KOta Surakarta, akb. Sragen dan Kab. Karanganyar). Jurnal Riset manajemen dan akuntansi, Vol. 4 Nomor 7 Edisi Mei. 
Fooster, B. (2001). Pembinaan Untuk Peningkatan Kinerja Karaywan. Jakarta: PPM.

Graevenitz, G. V., Harhoff, D., \& Weber, R. (Germany. 2010). The Effect Of Entrepreneurship Education. Journal Economic Behavior \& Organization.

Handoko, T. H. (n.d.). Paradigma Baru Manajemen Sumber Daya Mnausia. Yogyakarta: Amara Book.

Hatta, I. H. (2014). Analisis Pengaruh Inovasi, Pengambilan Risiko, Otonomi dan Reaksi Proaktif Terhadap Kapabilitas Pemasaran UKM Kuliner Daerah di Jabodetabek. Jurnal Manajermen, Vol.8 Nomor 2.

Hisrich, R. D., P.,, M., \& Shepherd, D. (2005). Entrepreneruship. New York: The McGraw-Hill Companies Inc.

Hodgetts, R., \& Kuratko, D. (2007). Entrepreneruship: Theory, Process, Practice (7th ed). Canada: Interactive Compotition Corporation.

Jackson, R. L. (2001). Manajemen Sumber Daya Manusia. Jakarta.

Lambing, P., \& Kuehl, C. (2000). Entrepreneurship. New Jersey: Prentice-Hall, Inc.

Megantoro, D. (2015). Pengaruh Keterampilan, Pengalaman dan Kemampuan SDM terhadap Usaha Kecil Menengah. Jurnal Bisnis dan Ekonomi.

Muhyi, H. A. (2012). Pengaruh Keterampilan Berwirausaha Terhadap Pertumbuhan Usaha Berkelanjutan Pada Industri Kecil di KOta Sukabumi. IJAD, Vol.2 Nomor 2.

Mulyadi, I. \&. (2016). Untuk menganalisis keterampilan wirausaha terhadap keberhasilan usaha. Journal of business management and enterpreneurhip education, Volume 1.

Nurhamsyah. (2014). Pengaruh Latar Belakang Sosial, Kemampuan Manajerial dan Pengalaman Terhadap Kinerja Usaha di Kota Batam. Jurnal Tepak Manajemen Bisnis, Vol. VI No. 1 Januari 2014 Fakultas Ekonomi Universitas Riau.

Pradanawati. (2015). Pengaruh tingkat pengalaman berwirausaha, produktivitas, dan inovasi terhadap pengembangan usaha kulit lumpia (studi kasus pada UMKM kulit lumpia di Semarang). Jurnal Nasional Universitas Dipenogoro.

Sudaresti. (2014). Hubungan Keterampilan dan Pekerjaan Terhadap Peningkatan Pendapatan Ibu Rumah Tangga Peserta Pelathiahn Enceng Gondok Usaha Kecil Menengah Luthfi Craft Di Desa Murtigading Piring II, Saden, Bantul. Tesis Tidak Diterbitkan.

Sugiono. (2016). Metode Penelitian Kuantitatif dan R\&D. Bandung: PT Alfabet.

Suryana. (2001). Kewirausahaan. In Pendekatan karakteristik kewirausahaan sukses (p. 30). Jakarta: Kencana Pranada Media Group.

Suryana. (2009). Kewirausahaan. In Pendekatan Karakteristik Wirausahaan Sukses (p. 88). Jakarta: Media Group.

Suryana. (2009). Kewirausahaan. In Pendekatan Karakteristik Wirausahawan Sukses (p. 91). Jakarta: Media Group.

Tavakoli, M., \& Fayolle, A. (2017). Entrepreneurship. In E. B. School, Entrepreneurship (p. 128). France: Elsivier inc.

Timmons, J. A., \& Spinelli, J. S. (2008). New Venture Creation. Kewirausahaan untuk Abad ke 21. Yogyakarta: Andi. (Buku asli New Venture Creation : Entrepreneurship for the 21 st Century 6th ed.).

Yunita. (2018, Juli 17). Detik.com. Retrieved Agustus 20, 2018, from http://finance.detik.com/berita-ekonomi-bisnis/d-4119386/jadi-penggerak-ekonomibegini-kondisi-UKM-RI 